\title{
Catenin Delta-1
}

National Cancer Institute

\section{Source}

National Cancer Institute. Catenin Delta-1. NCI Thesaurus. Code C79772.

Catenin delta-1 (968 aa, $108 \mathrm{kDa}$ ) is encoded by the human CT NND1 gene. This protein plays a role in receptor-mediated signaling. 